\title{
Oldoinyo Lengai Volcanic Ash for Removal of Hydrogen Sulfide and Ammonia from Biogas
}

\author{
Isack Kandola, Alexander Pogrebnoi, Tatiana Pogrebnaya \\ Department of Materials, Energy Science and Engineering, The Nelson Mandela African Institution of Science and Technology, \\ Arusha, Tanzania \\ Email: Kandolai@nm-aist.ac.tz
}

How to cite this paper: Kandola, I., Pogrebnoi, A. and Pogrebnaya, T. (2018) Oldoinyo Lengai Volcanic Ash for Removal of Hydrogen Sulfide and Ammonia from Biogas. Journal of Materials Science and Chemical Engineering, 6, 78-93.

https://doi.org/10.4236/msce.2018.64010

Received: February 19, 2018

Accepted: April 10, 2018

Published: April 13, 2018

Copyright () 2018 by authors and Scientific Research Publishing Inc. This work is licensed under the Creative Commons Attribution International License (CC BY 4.0).

http://creativecommons.org/licenses/by/4.0/

\begin{abstract}
Oldoinyo Lengai mountain located in Northern Tanzania is the only active natrocarbonatite volcano with unusually alkali-rich natrocarbonatites which are not found elsewhere in the world. Volcanic ash formed earlier during eruptions was collected from different sites along the mountain, and its potency to adsorb hydrogen sulfide $\left(\mathrm{H}_{2} \mathrm{~S}\right)$ and ammonia $\left(\mathrm{NH}_{3}\right)$ from biogas was investigated. The samples were calcinated at different temperatures $\left(550^{\circ} \mathrm{C}\right.$ $850^{\circ} \mathrm{C}$ ) and were characterized by X-ray florescent, scanning electron microscopy and X-ray diffraction techniques. The on-site adsorption experiments were conducted at the biogas digester at ambient conditions. The calcinated ash was packed into the reactor bed, biogas allowed to pass through the adsorbent, and the inlet and outlet concentrations of $\mathrm{H}_{2} \mathrm{~S}$ and $\mathrm{NH}_{3}$ were measured. The height of the site where the adsorbent was taken from, calcination temperature, biogas flowrate and mass of the adsorbent were variable parameters and found to influence greatly on the efficiency of $\mathrm{H}_{2} \mathrm{~S}$ and $\mathrm{NH}_{3}$ removal. The efficiency is increased with calcination temperature raise and mass of adsorbent and decreased with flowrate increase. The samples collected from the top site of the mountain and calcinated at $850^{\circ} \mathrm{C}$ exhibited the best sorption performance.
\end{abstract}

\section{Keywords}

Adsorption, Calcination, Flowrate, Oldoinyo Lengai, Volcanic Ash, $\mathrm{H}_{2} \mathrm{~S}$ and $\mathrm{NH}_{3}$ Removal

\section{Introduction}

Biogas produced by waste biomass becomes one of the vital substitute energy sources in recent years as it is obtained from non-fossil fuels [1]-[7]. The biogas consists of $\mathrm{CH}_{4}$ and $\mathrm{CO}_{2}$ which are the main constituents, but also contains in- 
sufficient amount of contaminants such as $\mathrm{H}_{2} \mathrm{~S}, \mathrm{NH}_{3}$, siloxanes and halogenated volatile organics [8] [9] [10] [11]. The hydrogen sulfide in biogas stream stands as extremely toxic gas which causes corrosion, erosion, fouling for metal devices such as, cooking stoves, biogas plants and steam turbines [12]. The presence of $\mathrm{H}_{2} \mathrm{~S}$ in combustion process results in formation of sulfur dioxide which is harmful for environment [13] [14], and injurious for human and animal health as it causes irritation of mucous membranes, headaches, dizziness, nausea and sudden death. For these motives, substantial attention has been paid to removal of $\mathrm{H}_{2} \mathrm{~S}$ from biogas stream prior to use.

Researchers focused on developing methods of $\mathrm{H}_{2} \mathrm{~S}$ removal from biogas stream. These methods are mainly directed in fabrication of various materials to adsorb and capture $\mathrm{H}_{2} \mathrm{~S}$ from gas streams [8] [9] [10] [11] [13] [15]-[21]. Currently, biogas sequestration through the adsorption process is a striking method due to its simplicity and low-cost materials such as natural clay soils and red mud soils [19] [20] [22] [23] [24] rich with iron oxide; the latter being oxidizing agent to convert $\mathrm{H}_{2} \mathrm{~S}$ to elemental sulfur which is a vital factor for biogas sequestration. Meanwhile, few studies have proposed the utilization of waste ashes (coal ash, biomass ash) [15] [25] [26] [27] [28], kaolin and modified crude clay [29] [30], Penausende muscovite [31], laterite [32], montmorillonite [33] [34], which are economically feasible for $\mathrm{CO}_{2}$ and $\mathrm{H}_{2} \mathrm{~S}$ removal.

Considering many benefits of biogas use as non-fossil fuel, it is imperative to develop cost effective adsorbents, easy way of removing toxic substances for application at medium and small-scale plants. Hence this current study aiming to investigate the removal of $\mathrm{H}_{2} \mathrm{~S}$ and $\mathrm{NH}_{3}$ from biogas using Oldoinyo Lengai volcanic ash (OLA) at ambient temperature conditions. The Oldoinyo Lengai is the only active natrocarbonatite volcano and it is a unique source of alkaline ash in the world; the OLA is abundant and readily available [35] [36] [37] [38]. The experiment was conducted on-site at The Banana investment company Ltd, Arusha, Tanzania where characteristics of $\mathrm{H}_{2} \mathrm{~S}$ and $\mathrm{NH}_{3}$ removal from biogas stream were determined at natural variation of biogas composition.

\section{Materials and Methods}

\subsection{Materials Collection and Preparation}

Ashes used in this study were collected from Oldoinyo Lengai volcano which is located Tanzania, the Rift Valley at $2^{\circ} 45^{\prime} \mathrm{S}, 35^{\circ} 55^{\prime} \mathrm{E}$ and $2000 \mathrm{~m}$ above the Serengeti plains [35] [37]. Several samples of ashes were randomly collected from various places on top, medium and bottom of the mountain. Previously it was found that the samples contain compounds of $\mathrm{K}, \mathrm{Na}, \mathrm{Ca}, \mathrm{Zn}$ and $\mathrm{Fe}$ [15] [38] [39] [40] which are potentially effective for $\mathrm{H}_{2} \mathrm{~S}$ and $\mathrm{NH}_{3}$ removal from biogas stream. The OLA samples were air dried, ground with a mortar and pestle, sieved to obtain the acquired particle size, below $2 \mathrm{~mm}$, and stored in vacuum desiccators until used. The samples were calcinated at different temperatures $T_{c}$, $550^{\circ} \mathrm{C}, 650^{\circ} \mathrm{C}, 750^{\circ} \mathrm{C}$, and $850^{\circ} \mathrm{C}$ for one hour in the oven (Thermo Scientific 
1200 Box furnace) and then allowed to cool; the heating rate was $10^{\circ} \mathrm{C} / \mathrm{min}$ and cooling rate $20^{\circ} \mathrm{C} / \mathrm{min}$. After the preliminary test on $\mathrm{H}_{2} \mathrm{~S}$ removal was performed, the best samples were retained for further investigations and detailed experiments. The selected samples were two from the top (OLA-TP and OLA-TN), two from medium (OLA-MN and OLA-MX) and one from bottom (OLA-BN), where TP and TN represent white ashes without and with plants, respectively; $\mathrm{MN}$ is white with plants and $\mathrm{MX}$ is a mixture of black and white ashes with plants. The notation of the samples also includes the calcination temperature, e.g. OLA-TP-850 implies the sample was collected at the top site of the mountain and calcinated at $850^{\circ} \mathrm{C}$. The raw materials taken at room temperature $\left(30^{\circ} \mathrm{C}\right)$ are denoted as OLA-TP-RT.

\subsection{Materials Characterization}

The oxides composition of the samples was determined by X-ray fluorescence spectrometer (XRF), model MiniPal4 (Pw4030)-Rh manufactured by PANalytical, using software provided with the instrument. A sample of $25 \mathrm{~g}$ of calcinated adsorbent was added to $100 \mathrm{ml}$ of distilled water. The mixture was stirred and shaken for one hour by using mechanical shaker (model AS200, RETSH Company). The $\mathrm{pH}$ of samples was measured with a $\mathrm{pH}$ meter, model H199121. The moisture content of raw OLA ashes determined under standard procedures as has been reported elsewhere [32] [41] was found to be $22.2 \% \pm 0.5 \%$. Mineral phase analysis and elemental oxide composition were analyzed by X-ray diffraction (XRD) technique using D2 phaser-Bruker model and X-ray diffraction meter with a $\mathrm{Cu}-\mathrm{K}_{\alpha}$ radiation source in a $2 \theta$ range between $10^{\circ}$ and $80^{\circ}$ at a scanning rate of $2^{\circ} \mathrm{min}^{-1}$ and analyzed using EVA software provided with the instrument.

The surface micromorphology of samples was investigated using a scanning electron microscope (SEM), modal JEOL JSM-6335F with resolution of $500 \mathrm{~nm}$, at $200 \mathrm{kV}$ at the Department of Materials Science and Engineering, University of Connecticut, USA.

\subsection{Measurements of $\mathrm{H}_{2} \mathrm{~S}$ and $\mathrm{NH}_{3}$ Removal and Evaluation of Sorption Capacity of Absorbents}

The sorption experiment of $\mathrm{H}_{2} \mathrm{~S}$ and $\mathrm{NH}_{3}$ was carried out at the Banana Investments company Ltd in Arusha, Tanzania where the biogas was produced from winery effluent banana industrial waste. The biogas was liberated from upflow anaerobic sludge blanket between 100 and $120 \mathrm{~m}^{3}$ daily, the composition of the gas was determined with the biogas $5000 \mathrm{~g}$ as analyzer to be $82 \%-89 \% \mathrm{CH}_{4}$, $12 \%-15 \% \mathrm{CO}_{2},<1 \% \mathrm{O}_{2}, 5-48$ ppm of $\mathrm{NH}_{3}$, and $24-60$ ppm of $\mathrm{H}_{2} \mathrm{~S}$ [42].

A reactor made of plastic tube, $6.5 \mathrm{~cm}$ length, $1.7 \mathrm{~cm}$ diameter, filled with adsorbent supported by cotton wool on both end sides of the reactor tube. The biogas allowed to flow through the reactor at ambient temperature varying the flowrate from 0.0004 to $0.008 \mathrm{~m}^{3} / \mathrm{min}$, and mass of adsorbents from 0.5 to $2.0 \mathrm{~g}$. 
The mass of adsorbent of $1 \mathrm{~g}$ and the biogas flowrate of $0.002 \mathrm{~m}^{3} / \mathrm{min}$ were used as standard parameters for this study. Schematic diagram and photos of the experimental setup are shown in Figure 1. The flowrate was controlled and monitored by using a flow meter, model JBD2.5-SA. The concentration of $\mathrm{H}_{2} \mathrm{~S}$ and $\mathrm{NH}_{3}$ was recorded at the inlet and outlet of the reactor with different time intervals from 5 to $150 \mathrm{~min}$. Breakthrough time $(B T)$ was noted when the outlet concentration $C_{\text {out }}$ of $\mathrm{H}_{2} \mathrm{~S}$ and $\mathrm{NH}_{3}$ reached $50 \%$ of the inlet concentration $C_{i n}$. The sorption tests were repeated at least twice for each sample.

The performance of material adsorbent was specified as percentage removal $R$ :

$$
R=\frac{C_{\text {in }}-C_{\text {out }}}{C_{\text {in }}} \times 100
$$

Sulfur sorption capacity (SC) of the OLA samples, in grams of sulfur per 100 grams of sorbent, was determined as described in [16] [43] [44];
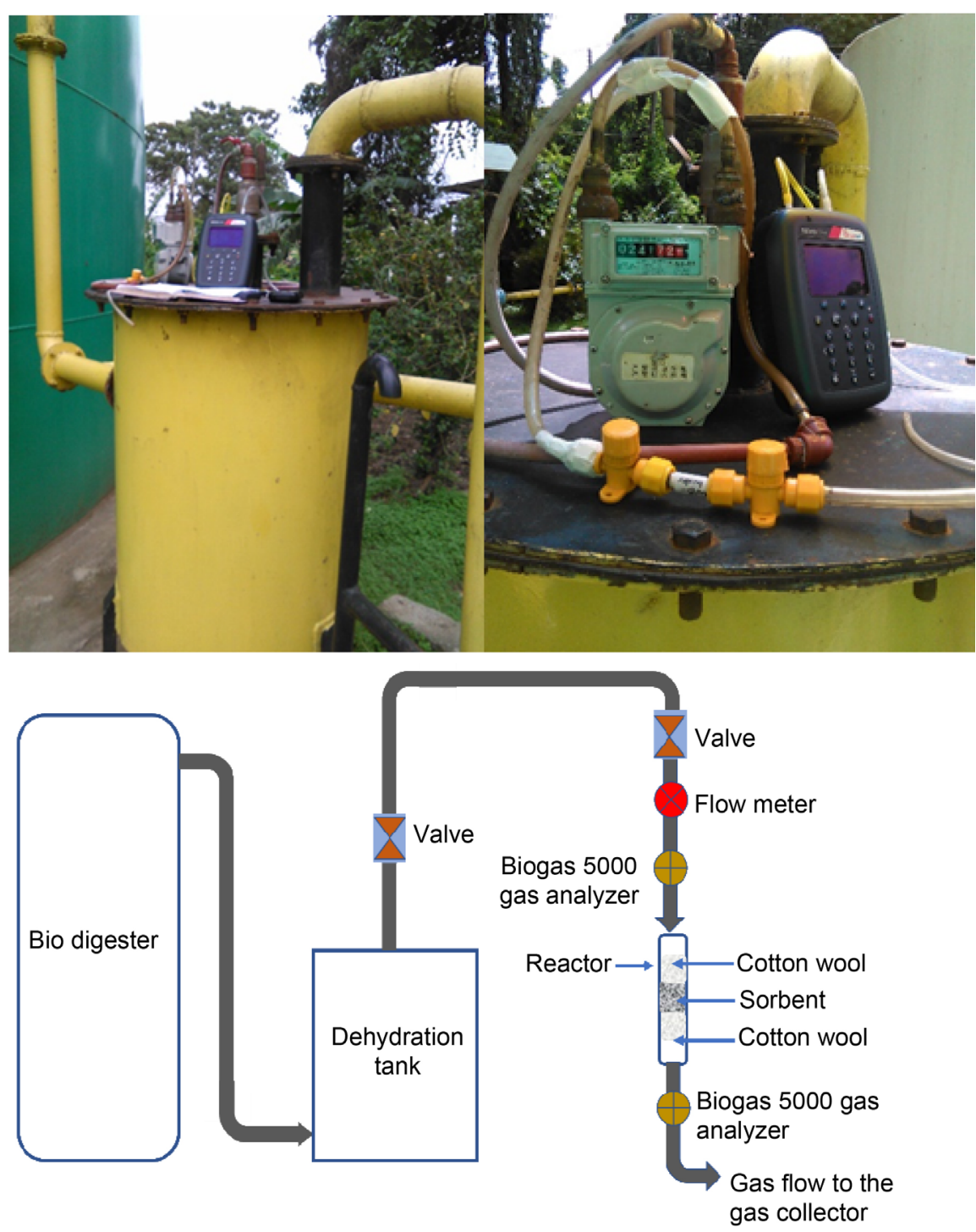

Figure 1. Photos and schematic diagram of the sorption experimental setup. 


$$
S C=G H S V \times\left[\frac{M}{V_{\text {mol }}} \times \int_{0}^{t}\left(C_{\text {in }}-C_{\text {out }}\right) \mathrm{d} t\right],
$$

where $G H S V$ is the gas hourly space velocity which is the volume of the gas flowing hourly through the reactor with $1 \mathrm{~g}$ of absorbent $\left(\mathrm{L} \cdot \mathrm{h}^{-1} \cdot \mathrm{g}^{-1}\right) ; V_{m o l}$ is the molar volume of the gas $\left(\mathrm{L} \cdot \mathrm{mol}^{-1}\right)$ under standard conditions, $M$ is the atomic mass of sulfur; $C_{\text {in }}$ and $C_{\text {out }}$ are the $\mathrm{H}_{2} \mathrm{~S}$ concentrations before and after sorption (ppm); $t$ is the breakthrough time in hours.

\section{Results and Discussion}

\subsection{XRF Analysis and pH of Raw OLA Samples}

Results on the XRF analysis of the raw OLA samples (Table 1) show that $\mathrm{Fe}_{2} \mathrm{O}_{3}$, $\mathrm{CaO}$ and $\mathrm{SiO}_{2}$ are most abundant components of all samples; alkali metal oxides are in essential amount, $\mathrm{K}_{2} \mathrm{O} \sim 3 \%-10 \%$ and $\mathrm{Na}_{2} \mathrm{O} \sim 2 \%-5 \%$. Some of transition and rare-earth elements were also found. As is seen the content of these oxides changes with height the samples were collected. The composition of the OLA samples is rather promising for $\mathrm{H}_{2} \mathrm{~S}$ removal due to, as it was observed earlier [15] [41] [45], Fe, K, Ca, Zn, Na, Ti, and Sr oxides may act as catalysts for oxidation of $\mathrm{H}_{2} \mathrm{~S}$.

The $\mathrm{pH}$ values of the OLA ashes are in the range of about $11-12$ and indicate materials' alkalinity which is evidently caused, according to [39], by presence of iron, calcium, potassium and sodium compounds. The basicity of the OLA ashes is expected to favour the hydrogen sulfide removal as it was shown for example in [45]. The mixed metal fly ashes [15] [25] [45], different metal oxides [15] [31] [33] [41] [46] [47] [48], coal ashes [15] [49] were successfully used for $\mathrm{H}_{2} \mathrm{~S}$

Table 1. The composition (wt\%) and $\mathrm{pH}$ values of Oldoinyo Lengai volcanic ash samples.

\begin{tabular}{cccccc}
\hline Oxides & OLA-TP & OLA-TN & OLA-MN & OLA-MX & OLA-BN \\
\hline $\mathrm{Fe}_{2} \mathrm{O}_{3}$ & 25.40 & 24.60 & 24.40 & 24.60 & 21.10 \\
$\mathrm{~K}_{2} \mathrm{O}$ & 5.40 & 2.80 & 9.71 & 2.82 & 4.29 \\
$\mathrm{CaO}$ & 46.00 & 46.00 & 36.80 & 36.50 & 36.00 \\
$\mathrm{ZnO}$ & 0.20 & 0.13 & 0.20 & 0.10 & 0.10 \\
$\mathrm{Al}_{2} \mathrm{O}_{3}$ & 5.60 & 1.30 & & & 1.90 \\
$\mathrm{SiO}_{2}$ & 5.10 & 11.00 & 19.40 & 21.20 & 24.00 \\
$\mathrm{TiO}_{2}$ & 2.40 & 2.50 & 2.78 & 2.62 & 2.99 \\
$\mathrm{BaO}$ & 1.30 & 2.00 & 1.00 & 1.80 & 1.30 \\
$\mathrm{Na}_{2} \mathrm{O}$ & 5.10 & 3.90 & 2.40 & 3.10 & 5.30 \\
$\mathrm{SrO}$ & 2.80 & 2.27 & 2.25 & 3.08 & 2.02 \\
$\mathrm{Eu}_{2} \mathrm{O}_{3}$ & 0.39 & 0.39 & 0.27 & 0.38 & 0.58 \\
$\mathrm{Nb}_{2} \mathrm{O}_{5}$ & 0.27 & 0.24 & 0.40 & 0.25 & 0.20 \\
$\mathrm{MoO}_{3}$ & 0.04 & 11.04 & 0.07 & & 11.06 \\
$\mathrm{Total}$ & 100 & & 99.68 & & \\
$\mathrm{pH}$ & 12.31 & & 10.91 & & \\
\hline
\end{tabular}


removal from biogas stream at ambient temperature.

The mechanism of the $\mathrm{H}_{2} \mathrm{~S}$ adsorption/oxidation processes was considered in [3] [12] [50] [51]; it was shown that inorganic materials containing active metal oxides participate in this process. The $\mathrm{H}_{2} \mathrm{~S}$ was oxidized to sulfur due to presence of moisture, which enabled dissociation of $\mathrm{H}_{2} \mathrm{~S}$ into $\mathrm{HS}^{-}$and then to elemental sulfur. These reactions were enhanced by basic $\mathrm{pH}$ of the adsorbent [3] [48].

\subsection{XRD Analysis of Calcinated OLA Samples}

The XRD spectra were measured for several samples; an example for the OLA-TP-850 is shown in Figure 2. The data indicate the crystalline solid form of the materials where compounds of iron, sodium, calcium and potassium are identified as main components by peaks of magnetite $\left(2 \theta=35.5^{\circ}, 43^{\circ}, 57^{\circ}, 63^{\circ}\right)$, analcime $\left(2 \theta=16^{\circ}, 18^{\circ}, 26^{\circ}\right)$, epidote $\left(2 \theta=31^{\circ}, 56^{\circ}\right)$ and nepheline $\left(2 \theta=21^{\circ}\right.$, $23^{\circ}, 27^{\circ}, 29.8^{\circ}, 37^{\circ}$ ), respectively. These results are in accordance with the data reported previously [39]. For the sample after absorption, the additional peaks were recorded at $2 \theta=22^{\circ}, 31^{\circ}, 32.5^{\circ}$ and $49^{\circ}$ which correspond to sodium hydrogen sulfate $\mathrm{Na}_{3} \mathrm{H}\left(\mathrm{SO}_{4}\right)_{2}$. The formation of this compound indicates interaction of hydrogen sulfide with the adsorbent and hence chemisorption occurrence. Our results differ from those published [19] in which red mud was used for $\mathrm{H}_{2} \mathrm{~S}$ removal, and after sorption $\mathrm{FeS}_{2}, \mathrm{FeS}, \mathrm{CaSO}_{4} \cdot 2 \mathrm{H}_{2} \mathrm{O}$, sulfur, sodium sulfide and bisulfide were formed.

Apparently, the distinction of our results with literature [19] may be attributed to the different mineralogical and chemical composition of the adsorbents.

\subsection{SEM Surface Micromorphology Analysis}

The surface morphology of samples was investigated using SEM; an example shown in Figure 3 for OLA-TP-850. The surface features indicate considerable

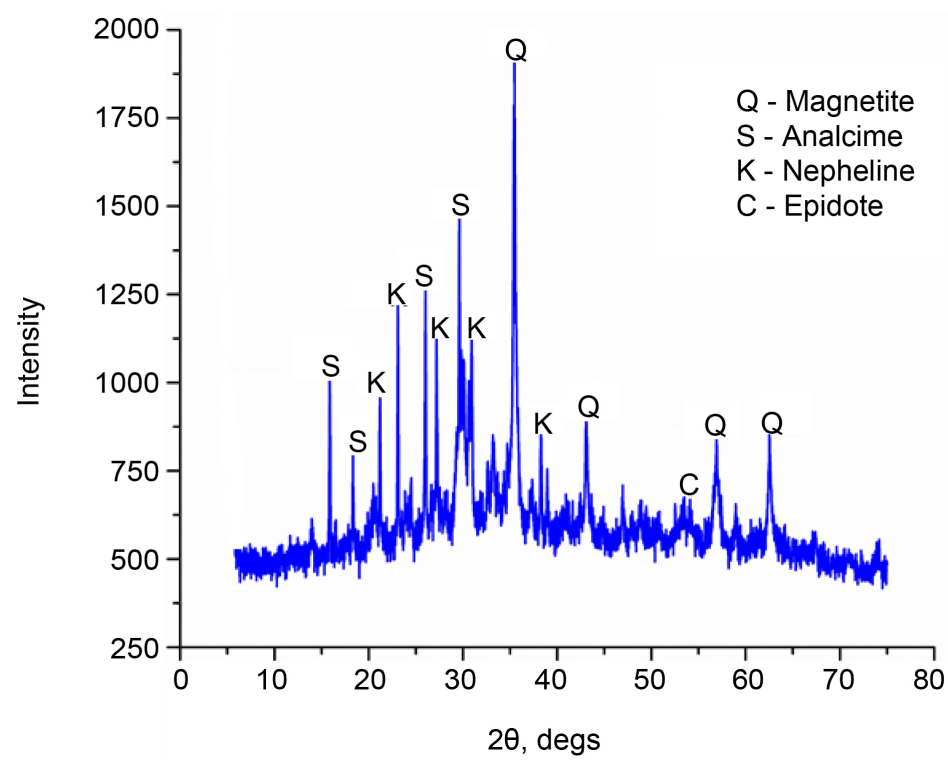

Figure 2. XRD patterns for OLA-TP-850 sample before adsorption. 


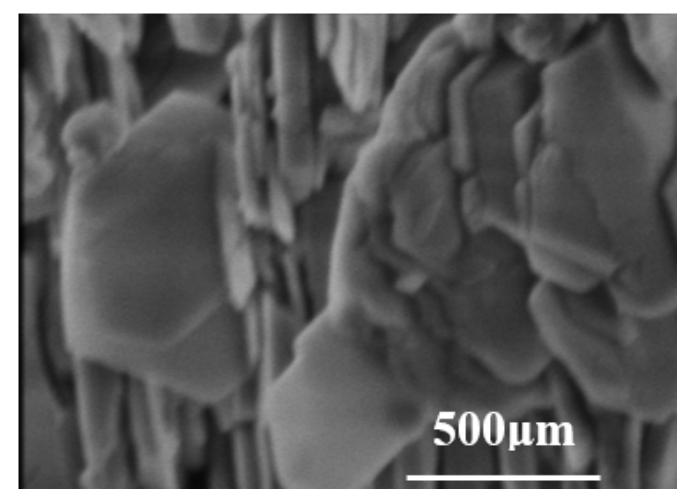

Figure 3. Surface morphology of OLA-TP-850 sample before adsorption.

porosity which evidently may provide efficient physisorption.

It was observed earlier that the porous structure and surface chemistry of the adsorbent had significant effect on adsorption and oxidation of hydrogen sulfide [33]. Besides the morphology of ashes is controlled by calcination temperature, and porosity increases with $T_{\mathrm{c}}$ increase [51]. We may expect that our samples which were calcinated at higher temperatures would demonstrate better adsorption performance.

\subsection{Adsorption Performance of OLA Samples}

\subsubsection{Effect of Calcination Temperature and Height the Samples Were Collected}

The values of sorption capacity calculated using Equation (2) and breakthrough time are given in Table 2 for different OLAs. The effect of calcination temperature and height of sites the samples were collected on the sorption capacity is depicted also in the diagram (Figure 4). As is seen, the $S C$ is increased with calcination temperature raise; e.g., the ashes taken without calcinations, OLA-TP-RT, and calcinated at $850^{\circ} \mathrm{C}$, OLA-TP-850, result in the $S C$ of $\sim 0.2$ and $\sim 1.0 \mathrm{~g} \mathrm{~S} / 100 \mathrm{~g}$ of adsorbent, respectively. It is also observed that the $S C$ increases with height of site; the samples collected at the top and calcinated at $850^{\circ} \mathrm{C}$, OLA-TP-850, demonstrate the best performance. The breakthrough time relates to the life time of the adsorbent; the longer is the $B T$, the higher is the working capability of the material. One can see the $B T$ increases greatly with height (from $5 \mathrm{~min}$ for OLA-BN-650 to $120 \mathrm{~min}$ for OLA-TN-650) and calcination temperature raise (from $55 \mathrm{~min}$ for the OLA-TP-RT up to $177 \mathrm{~min}$ for OLA-TP-850). Thus, the OLA-TP-850 samples possess the longest working time.

The adsorption efficiency removal $R$ was measured both for $\mathrm{H}_{2} \mathrm{~S}$ and $\mathrm{NH}_{3}$ and analyzed for different samples with respect to time interval between the measurements of initial and final concentrations of the adsorbates while biogas flowed through the reactor. The plots for Rvs time for the samples collected at different heights and calcinated at $850^{\circ} \mathrm{C}$ are shown in Figure 5. Results indicate the removal efficiency decreases with time for all samples. For the OLA-TP-850, $R$ reduces by $\sim 10 \%$ both for $\mathrm{H}_{2} \mathrm{~S}$ and $\mathrm{NH}_{3}$ after one hour of the adsorbent's use. 
Table 2. Adsorption performance of different OLA samples for $\mathrm{H}_{2} \mathrm{~S}$ removal: sorption capacity and breakthrough time; mass of adsorbent $1 \mathrm{~g}$ and the biogas flowrate 0.002 $\mathrm{m}^{3} / \mathrm{min}$.

\begin{tabular}{ccc}
\hline Sample & $S C$, g of S/100g of adsorbent & $B T$, min \\
\hline OLA-TP-RT & 0.24 & 55 \\
OLA-TN-RT & 0.21 & 35 \\
OLA-MN-RT & 0.08 & 20 \\
OLA-TP-550 & 0.65 & 120 \\
OLA-TN-550 & 0.37 & 80 \\
OLA-MN-550 & 0.17 & 35 \\
OLA-MX-550 & 0.05 & 10 \\
OLA-TP-650 & 0.82 & 150 \\
OLA-TN-650 & 0.53 & 120 \\
OLA-MN-650 & 0.35 & 80 \\
OLA-MX-650 & 0.16 & 35 \\
OLA-BN-650 & 0.02 & 5 \\
OLA-TP-750 & 0.90 & 165 \\
OLA-TN-750 & 0.58 & 150 \\
OLA-MN-750 & 0.47 & 120 \\
OLA-MX-750 & 0.18 & 35 \\
OLA-BN-750 & 0.03 & 55 \\
OLA-TP-850 & 1.00 & 150 \\
OLA-TN-850 & 0.67 & 10 \\
OLA-MN-850 & 0.59 & 55 \\
OLA-MX-850 & 0.25 & \\
OLA-BN-850 & 0.04 & 120 \\
OLA & & 35 \\
\hline
\end{tabular}

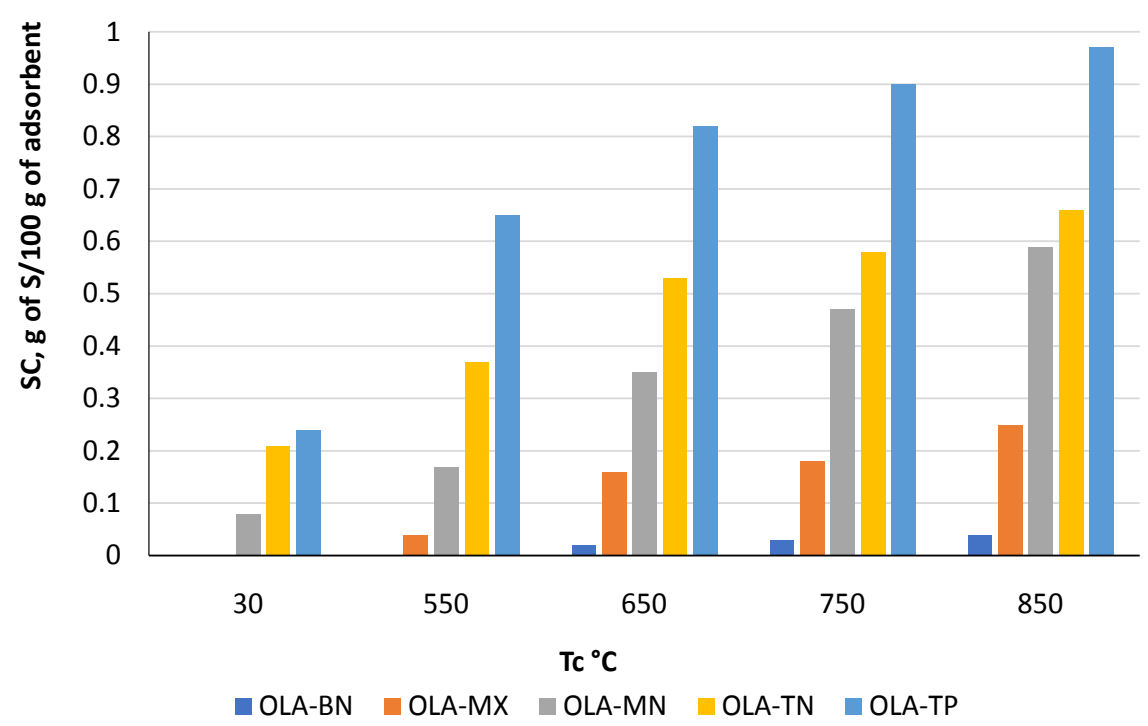

Figure 4. Sorption capacity of Oldoinyo Lengai ash materials for hydrogen sulfide removal; mass of adsorbent $1 \mathrm{~g}$ and the biogas flowrate $0.002 \mathrm{~m}^{3} / \mathrm{min}$. 


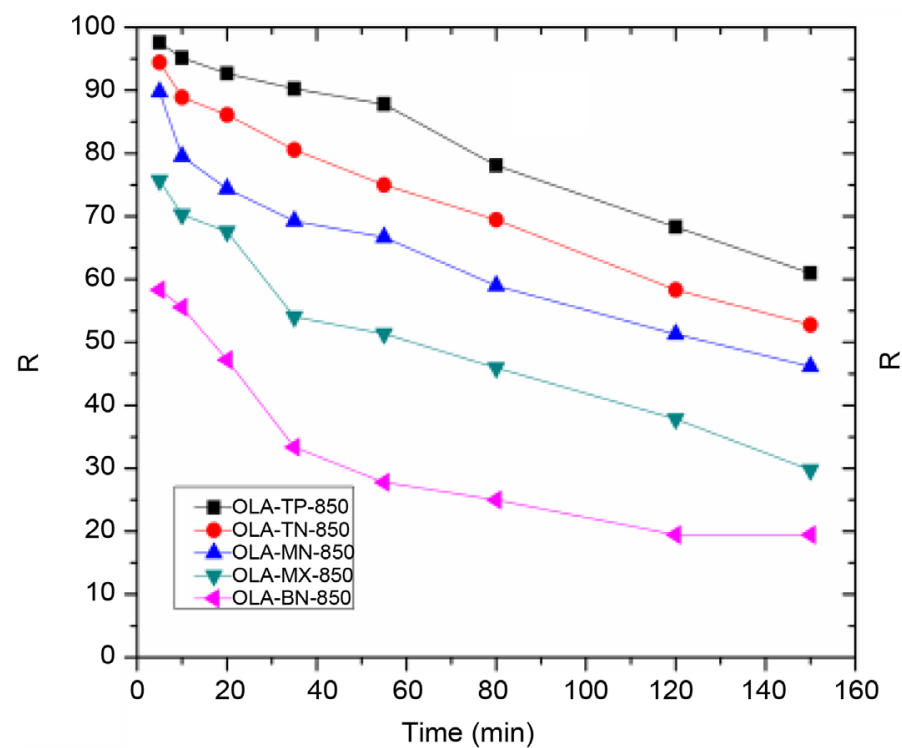

(a)

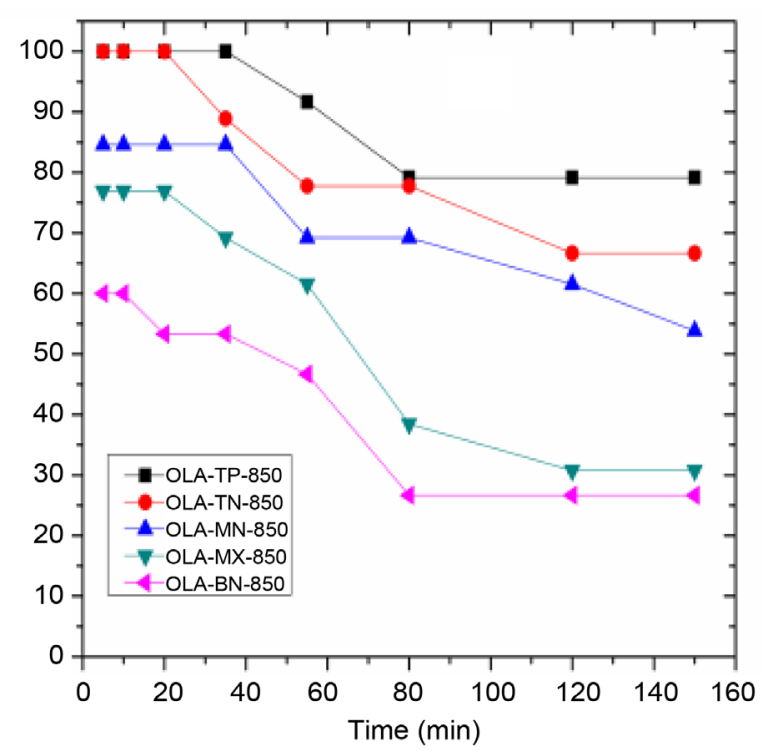

(b)

Figure 5. Effect of the site location on the removal efficiency of $\mathrm{H}_{2} \mathrm{~S}$ (a) and $\mathrm{NH}_{3}$ (b); for all samples $T_{\mathrm{c}}=850^{\circ} \mathrm{C}$, flowrate 0.002 $\mathrm{m}^{3} / \mathrm{min}$, mass of the adsorbent $1 \mathrm{~g}$.

Similar trend is observed in Figure 6 where the plots of Rvs time are given for OLA-TP samples calcinated at different temperatures. The removal efficiency is increased with calcination temperature raise. Thus after $150 \mathrm{~min}$ of the absorbent's use, the $R$ of OLA-TP-RT descents to $37 \%$, while the OLA-TP- 850 holds $60 \%$ for $\mathrm{H}_{2} \mathrm{~S}$ removal; for ammonia, the values of $R$ are $40 \%$ and $80 \%$, respectively. Based on the results of [33] [52] [53], we suggest that the increase in adsorption efficiency with temperature $T_{\mathrm{c}}$ may be caused by increase of number of pores created in adsorbents. On the other hand, the removal efficiency decreases in time because the surface of adsorbent is being occupied with the adsorbate molecules and the porosity is reduced as the pores are clogging with the gas molecules [32].

If compare the plots of $R v s$ time for $\mathrm{H}_{2} \mathrm{~S}$ and $\mathrm{NH}_{3}$, they look differently: monotonic decay for the former and step-like for latter. The step-like behavior for ammonia may be attributed to rather low concentration $\left(C_{\text {in }} \sim 0.005 \mathrm{mg} \mathrm{NH}_{3}\right.$ per $1 \mathrm{~g}$ of the biogas, that is one order less than of $\mathrm{H}_{2} \mathrm{~S}$ ) measured at the sensitivity limit of the gas analyzers. Moreover, according to Equation (2), the lower input concentration of ammonia also brings bigger value of $R$.

Therefore, among all OLA samples considered the ashes collected at the top site and calcinated at $850^{\circ} \mathrm{C}$, the OLA-TP-850, demonstrated the best removal efficiency retaining it high during the exploitation time of the adsorbent.

\subsubsection{Effect of Biogas Flowrate}

The effect of biogas flowrate on the samples adsorption performance was investigated; the flowrates were $0.0004,0.001,0.002$, and $0.008 \mathrm{~m}^{3} / \mathrm{min}$. The values of the removal efficiency of $\mathrm{H}_{2} \mathrm{~S}$ and $\mathrm{NH}_{3}$ are plotted $v s$ time for the top-site samples OLA-TP-850 in Figure 7. One can see, with the flowrate raise from 0.0004 


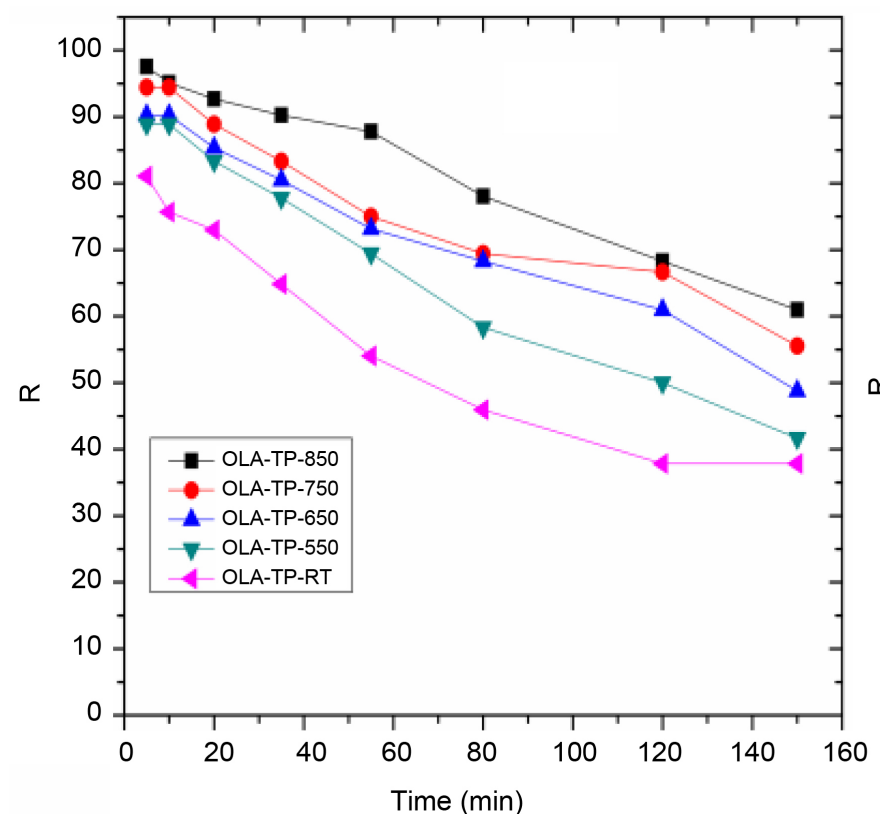

(a)

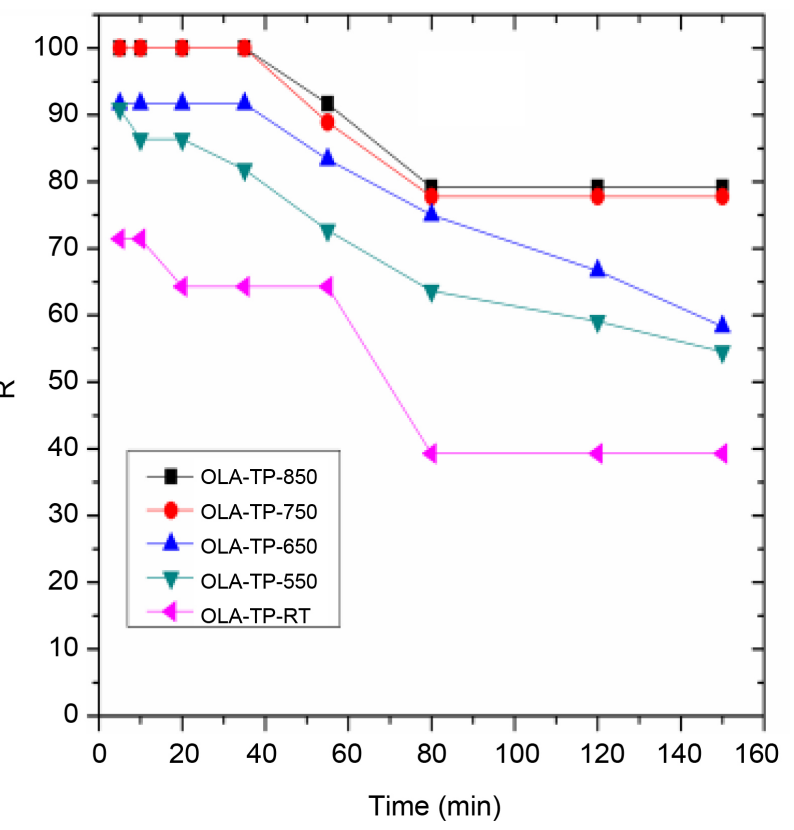

(b)

Figure 6. Effect of calcination temperature on removal efficiency of $\mathrm{H}_{2} \mathrm{~S}$ (a) and $\mathrm{NH}_{3}$ (b); OLA-TP samples, flowrate 0.002 $\mathrm{m}^{3} / \mathrm{min}$, mass of the adsorbent $1 \mathrm{~g}$.

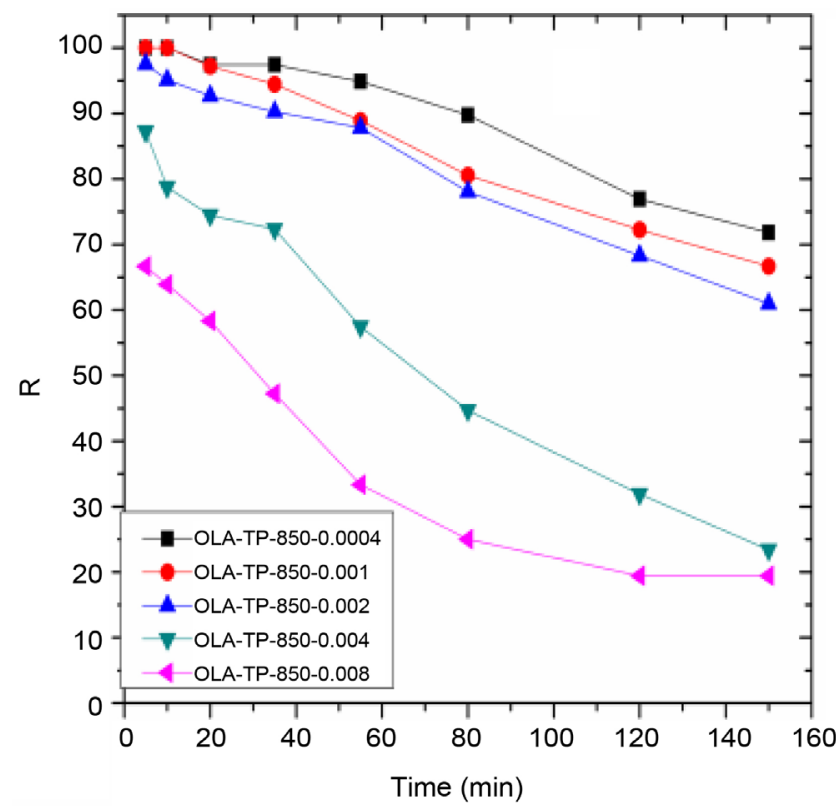

(a)

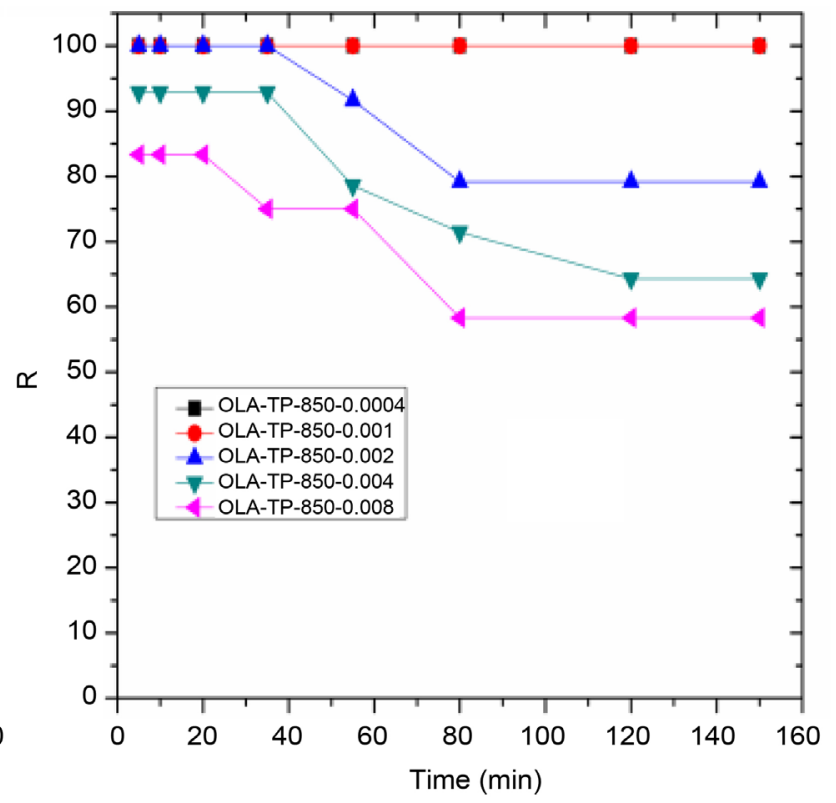

(b)

Figure 7. Effect of biogas flowrate on removal efficiency of $\mathrm{H}_{2} \mathrm{~S}$ (a) and $\mathrm{NH}_{3}$ (b); OLA-TP-850, mass of the adsorbent $1 \mathrm{~g}$.

to $0.008 \mathrm{~m}^{3} / \mathrm{min}$ the $R$ values decrease from $71 \%$ to $20 \%$ for $\mathrm{H}_{2} \mathrm{~S}$ and from $100 \%$ to $58 \%$ for $\mathrm{NH}_{3}$, respectively, measured after 150 min adsorbent's use.

It seems at low flowrate $\left(0.0004 \mathrm{~m}^{3} / \mathrm{min}\right)$ the materials get enough contact time for interaction between gas molecules and adsorbent; whereas at high flowrate $\left(0.008 \mathrm{~m}^{3} / \mathrm{min}\right), \mathrm{H}_{2} \mathrm{~S}$ and $\mathrm{NH}_{3}$ gas molecules can pass through without being adsorbed and reacted fully with adsorbent. Therefore, the contact time be- 


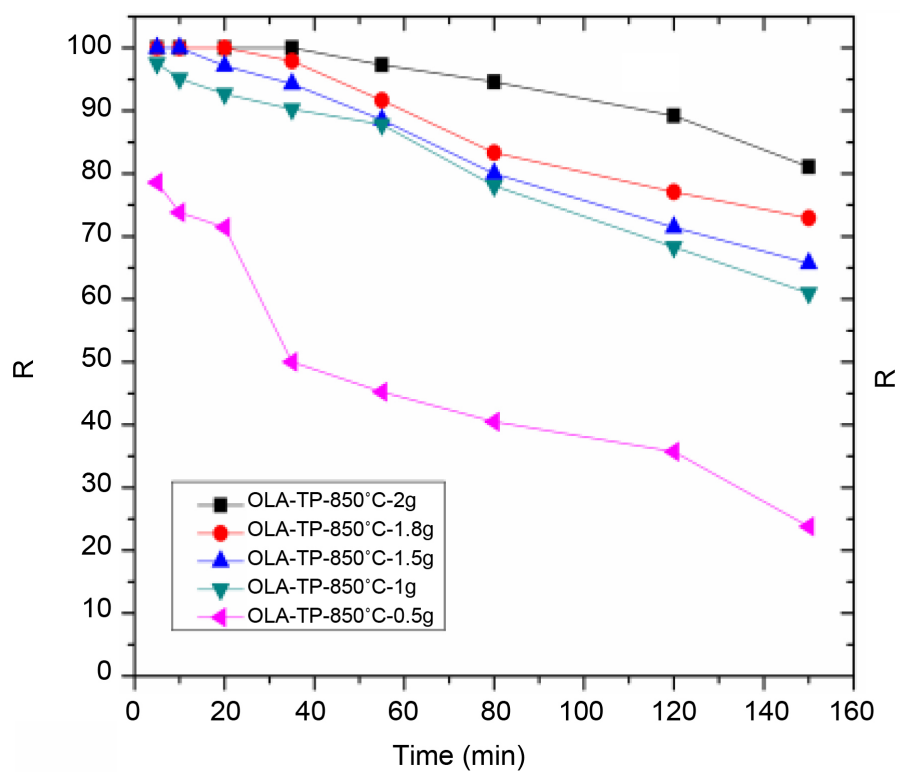

(a)

tween gas and adsorbent is significant in determining the adsorption capacity. This is in accordance with findings reported in [48].

\subsubsection{Effect of Mass of Adsorbent Material}

The effect of variation of the absorbent mass, from 0.5 to $2.0 \mathrm{~g}$, on the removal efficiency of $\mathrm{H}_{2} \mathrm{~S}$ and $\mathrm{NH}_{3}$; was considered for the samples OLA-TP-850 (Figure 8). The results indicate that $R$ values evidently increase with mass. Four-fold enlargement in mass leads to essential increase in removal efficiency, from 23 to $80 \%$ for $\mathrm{H}_{2} \mathrm{~S}$ and from $50 \%$ to $100 \%$ for $\mathrm{NH}_{3}$ measured after 150 min adsorbent's use. When the mass of adsorbent was $2 \mathrm{~g}$, the material retained $100 \% \mathrm{H}_{2} \mathrm{~S}$ removal after $40 \mathrm{~min}$ and efficiency decreased to $80 \%$ after $150 \mathrm{~min}$; while for $\mathrm{NH}_{3}$ the adsorbent held $100 \%$ removal efficiency for all time measurements.

\subsubsection{Comparison of OLA-TP-850 with Other Materials}

The adsorption properties of our best sample OLA-TP-850 are compared to other materials reported in literature (Table 3 ).

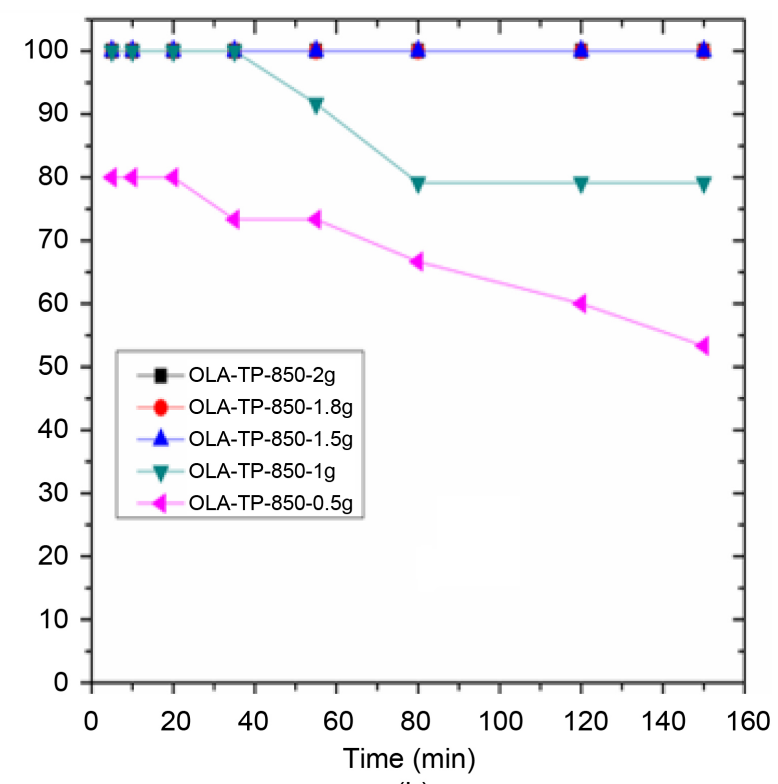

(b)

Figure 8. Effect of adsorbent mass on removal efficiency of $\mathrm{H}_{2} \mathrm{~S}$ (a) and $\mathrm{NH}_{3}$ (b); OLA-TP-850, flowrate $0.002 \mathrm{~m}^{3} / \mathrm{min}^{\text {. }}$

Table 3. Adsorption properties of OLA-TP-850 compared to other materials.

\begin{tabular}{|c|c|c|c|c|c|}
\hline Adsorbent & Mass, g & $\begin{array}{l}\text { Biogas flowrate, } \\
\mathrm{m}^{3} / \mathrm{min}\end{array}$ & $\begin{array}{c}\mathrm{H}_{2} \mathrm{~S} \text { removal, g S/100g } \\
\text { of adsorbent }\end{array}$ & $\mathrm{pH}$ & Ref. \\
\hline Moist soils & $1-5$ & $8.00 \times 10^{-5}$ & 0.50 & $5.70-7.70$ & {$[54]$} \\
\hline Montmorillonite clay & 12.50 & $51.00 \times 10^{-2}$ & 1.27 & 9.00 & [33] \\
\hline $\begin{array}{l}\text { Municipal waste } \\
\text { bottom ash }\end{array}$ & $13 \times 10^{3}$ & $55.94 \times 10^{-3}$ & 0.30 & 9.80 & [55] \\
\hline Red mud soil & 5 & $5 \times 10^{-5}$ & 2.10 & $>13.00$ & [19] \\
\hline Coal ashes & 10 & $14.20 \times 10^{-5}$ & 0.50 & $11.90 \pm 0.01$ & [15] \\
\hline OLA-TP-850 & 1 & $2 \times 10^{-3}$ & 1.00 & 12.31 & Current study \\
\hline
\end{tabular}


The sorption capacity of OLA ashes appeared to be close to the commercial montmorillonite clay and higher than other natural materials used for $\mathrm{H}_{2} \mathrm{~S}$ removal, e.g. municipal waste bottom ash, coal ashes etc. Meanwhile, when different samples are compared it is worth to take into account the effect of experimental conditions like the biogas flowrate and $\mathrm{pH}$; as it was mentioned above, the lower flowrate and basicity of the sorbent favour the hydrogen sulfide removal. Thus, the Oldoinyo Lengai volcanic ashes can be used as adsorbents for $\mathrm{H}_{2} \mathrm{~S}$ and $\mathrm{NH}_{3}$ removal in biogas plant industries, however further improvement of the adsorption properties may be suggested, e.g., increasing of calcination temperature and activation with chemical reagents.

\section{Conclusion}

A potency of the Oldoinyo Lengai volcanic ashes on removal of hydrogen sulfide and ammonia from biogas stream was investigated. Sorption capacity and removal efficiency were measured for different OLA samples at ambient temperature. The materials were examined in the on-site experiment at real industrial conditions. The best materials demonstrated long-lasting sorption ability. The XRD and XRF spectra of the OLA samples were examined. Mineralogical composition analysis exhibited an abundance of compounds of iron, alkali and alkali-earthmetals; rare-earth metals compounds were also found. The high porosity of samples favoured physisorption of $\mathrm{H}_{2} \mathrm{~S}$ and $\mathrm{NH}_{3}$. Moreover, chemisorption of $\mathrm{H}_{2} \mathrm{~S}$ was confirmed via formation of sodium sulfate-sodium bisulfate. In our on-site experiment the biogas flowrate and mass of adsorbent were variable parameters. The inlet concentration of $\mathrm{H}_{2} \mathrm{~S}$ in biogas was controlled but difficult to keep constant. For the next step, it may be recommended to evaluate the effect of concentration of $\mathrm{H}_{2} \mathrm{~S}$ and $\mathrm{NH}_{3}$ on the sorption capacity of the samples in laboratory conditions.

\section{Acknowledgements}

The authors thank the German Academic Exchange Service DAAD, for the award of the scholarship which catered for paying tuition fees and accommodation to undertake the MSc studies at The Nelson Mandela African Institution of Science and Technology. Prof. K. Njau through VLIR-IUC/NM-AIST partnership programme is highly acknowledged for the financial support and Department of Materials Science and Engineering, University of Connecticut, USA, for scanning electron microscope (SEM) analysis allowed to render this study.

\section{Conflict of Interest}

The authors have not declared any conflict of interest.

\section{References}

[1] Niesner, J., Jecha, D. and Stehlík, P. (2013) Biogas Upgrading Technologies: State of art Review in European Region. Chemical Engineering Transactions, 35, 517-522. 
[2] Florin, N.H. and Harris, A.T. (2008) Enhanced Hydrogen Production from Biomass with in situ Carbon Dioxide Capture Using Calcium Oxide Sorbents. Chemical Engineering Science, 63, 287-316. https://doi.org/10.1016/j.ces.2007.09.011

[3] Adib, F., Bagreev, A. and Bandosz, T.J. (1999) Effect of pH and Surface Chemistry on the Mechanism of $\mathrm{H}_{2} \mathrm{~S}$ Removal by Activated Carbons. Journal of Colloid and Interface Science, 216, 360-369. https://doi.org/10.1006/jcis.1999.6335

[4] Zulkeflia, N.N. and Masdara, M.S. (2016) Overview of $\mathrm{H}_{2} \mathrm{~S}$ Removal Technologies from Biogas Production. International Journal of Applied Engineering Research, 11, 10060-10066.

[5] Barelli, L., Bidini, G., Hernàndez-Balada, E., Mata-Álvarez, J. and Sisani, E. (2017) Performance Characterization of a Novel Fe-Based Sorbent for Anaerobic Gas Desulfurization Finalized to High Temperature Fuel Cell Applications. International Journal of Hydrogen Energy, 42, 1859-1874.

https://doi.org/10.1016/j.ijhydene.2016.09.070

[6] Arnold, M. and Kajolinna, T. (2010) Development of On-Line Measurement Techniques for Siloxanes and Other Trace Compounds in Biogas. Waste Management, 30, 1011-1017. https://doi.org/10.1016/j.wasman.2009.11.030

[7] Al Mamun, M.R. and Torii, S. (2015) Removal of Hydrogen Sulfide $\left(\mathrm{H}_{2} \mathrm{~S}\right)$ from Biogas Using Zero-Valent Iron. Journal of Clean Energy Technologies, 3, 428-432. https://doi.org/10.7763/JOCET.2015.V3.236

[8] Karmakar, M.K., Chandra, P. and Chatterjee, P.K. (2015) A Review on the Fuel Gas Cleaning Technologies in Gasification Process. Journal of Environmental Chemical Engineering, 3, 689-702. https://doi.org/10.1016/j.jece.2015.02.011

[9] Awe, O.W., Zhao, Y., Nzihou, A., Minh, D.P. and Lyczko, N. (2017) A Review of Biogas Utilisation, Purification and Upgrading Technologies. Waste and Biomass Valorization, 8, 267-283. https://doi.org/10.1007/s12649-016-9826-4

[10] Abatzoglou, N. and Boivin, S. (2009) A Review of Biogas Purification Processes. Biofuels, Bioproducts and Biorefining, 3, 42-71. https://doi.org/10.1002/bbb.117

[11] Miltner, M., Makarukb, A. and Haraseka, M. (2016) Selected Methods of Advanced Biogas Upgrading. Chemical Engineering Transactions, 52, 463-468.

[12] Bagreev, A. and Bandosz, T.J. (2005) On the Mechanism of Hydrogen Sulfide Removal from Moist Air on Catalytic Carbonaceous Adsorbents. Industrial \& Engineering Chemistry Research, 44, 530-538. https://doi.org/10.1021/ie049277o

[13] Sun, Q., Li, H., Yan, J., Liu, L., Yu, Z. and Yu, X. (2015) Selection of Appropriate Biogas Upgrading Technology-A Review of Biogas Cleaning, Upgrading and Utilisation. Renewable and Sustainable Energy Reviews, 51, 521-532. https://doi.org/10.1016/j.rser.2015.06.029

[14] Tippayawong, N. and Thanompongchart, P. (2010) Biogas Quality Upgrade by Simultaneous Removal of $\mathrm{CO}_{2}$ and $\mathrm{H}_{2} \mathrm{~S}$ in a Packed Column Reactor. Energy, 35, 4531-4535. https://doi.org/10.1016/j.energy.2010.04.014

[15] Kastner, J.R., Das, K. and Melear, N.D. (2002) Catalytic Oxidation of Gaseous Reduced Sulfur Compounds Using Coal Fly Ash. Journal of Hazardous Materials, 95, 81-90. https://doi.org/10.1016/S0304-3894(02)00055-9

[16] Kim, K., Jeon, S., Vo, C., Park, C.S. and Norbeck, J.M. (2007) Removal of Hydrogen Sulfide from a Steam-Hydrogasifier Product Gas by Zinc Oxide Sorbent. Industrial \& Engineering Chemistry Research, 46, 5848-5854. https://doi.org/10.1021/ie0614531

[17] Bagreev, A., Bashkova, S., Locke, D.C. and Bandosz, T.J. (2001) Sewage 
Sludge-Derived Materials as Efficient Adsorbents for Removal of Hydrogen Sulfide. Environmental Science \& Technology, 35, 1537-1543. https://doi.org/10.1021/es001678h

[18] Siefers, A., Wang, N., Sindt, A., Dunn, J., McElvogue, J., Evans, E. and Ellis, T. (2010) A Novel and Cost-Effective Hydrogen Sulfide Removal Technology Using Tire Derived Rubber Particles. Graduate Theses and Dissertations, Iowa State University, Ames. https://doi.org/10.2175/193864710798182682

[19] Sahu, R.C., Patel, R. and Ray, B.C. (2011) Removal of Hydrogen Sulfide Using Red Mud at Ambient Conditions. Fuel Processing Technology, 92, 1587-1592. https://doi.org/10.1016/j.fuproc.2011.04.002

[20] Ko, T. and Chu, H. (2005) Spectroscopic Study on Sorption of Hydrogen Sulfide by Means of Red Soil. Spectrochimica Acta Part A: Molecular and Biomolecular Spectroscopy, 61, 2253-2259. https://doi.org/10.1016/j.saa.2004.09.016

[21] Masebinu, S., Aboyade, A. and Muzenda, E. (2014) Enrichment of Biogas for Use as Vehicular Fuel: A Review of the Upgrading Techniques. International Journal of Research in Chemical, Metallurgical and Civil Engineering, 1, 89-98.

[22] Ismadji, S., Soetaredjo, F.E. and Ayucitra, A. (2015) Natural Clay Minerals as Environmental Cleaning Agents. In: Clay Materials for Environmental Remediation, Springer, Manhattan, 5-37.

[23] Ko, T.H., Chu, H. and Tseng, J.J. (2006) Feasibility Study on High-Temperature Sorption of Hydrogen Sulfide by Natural Soils. Chemosphere, 64, 881-891. https://doi.org/10.1016/j.chemosphere.2006.01.056

[24] Long, N.Q. and Loc, T.X. (2016) Experimental and Modeling Study on Room-Temperature Removal of Hydrogen Sulfide using a Low-Cost Extruded $\mathrm{Fe}_{2} \mathrm{O}_{3}$-Based Adsorbent. Adsorption, 22, 397-408. https://doi.org/10.1007/s10450-016-9790-0

[25] Ho, C.U.-S. and Shih, S.-M. (1992) $\mathrm{Ca}(\mathrm{OH})_{2} /$ Fly Ash Sorbents for $\mathrm{SO}_{2}$ Removal. Industrial and Engineering Chemistry Research, 31, 1130-1135.

[26] Vassilev, S.V., Baxter, D., Andersen, L.K. and Vassileva, C.G. (2010) An Overview of the Chemical Composition of Biomass. Fuel, 89, 913-933. https://doi.org/10.1016/j.fuel.2009.10.022

[27] Lam, C.H., Ip, A.W., Barford, J.P. and McKay, G. (2010) Use of Incineration MSW Ash: A Review. Sustainability, 2, 1943-1968. https://doi.org/10.3390/su2071943

[28] Andersson, J. and Nordberg, Å. (2017) Biogas Upgrading Using Ash from Combustion of Wood Fuels: Laboratory Experiments. Energy and Environment Research, 7, 38. https://doi.org/10.5539/eer.v7n1p38

[29] Louhichi, S., Ghorbel, A., Chekir, H., Trabelsi, N. and Khemakhem, S. (2016) Properties of Modified Crude Clay by Iron and Copper Nanoparticles as Potential Hydrogen Sulfide Adsorption. Applied Clay Science, 127, 123-128. https://doi.org/10.1016/j.clay.2016.04.007

[30] Abdullah, A.H., Mat, R., Abd Aziz, A.S. and Roslan, F. (2017) Use of Kaolin as Adsorbent for Removal of Hydrogen Sulphide from Biogas. Chemical Engineering Transactions, 56, 763-768.

[31] Sánchez-Martín, M., Dorado, M., Del Hoyo, C. and Rodríguez-Cruz, M. (2008) Influence of Clay Mineral Structure and Surfactant Nature on the Adsorption Capacity of Surfactants by Clays. Journal of Hazardous Materials, 150, 115-123. https://doi.org/10.1016/j.jhazmat.2007.04.093

[32] Thanakunpaisit, N. and Jantarachat, N. (2017) Removal of Hydrogen Sulfide from 
Biogas using Laterite Materials as an Adsorbent. Energy Procedia, 138, 1134-1139. https://doi.org/10.1016/j.egypro.2017.10.215

[33] Nguyen-Thanh, D., Block, K. and Bandosz, T.J. (2005) Adsorption of Hydrogen Sulfide on Montmorillonites Modified with Iron. Chemosphere, 59, 343-353. https://doi.org/10.1016/j.chemosphere.2004.10.022

[34] Jiang, J.-Q. and Zeng, Z. (2003) Comparison of Modified Montmorillonite Adsorbents: Part II: The Effects of the Type of Raw Clays and Modification Conditions on the Adsorption Performance. Chemosphere, 53, 53-62. https://doi.org/10.1016/S0045-6535(03)00449-1

[35] De Schutter, A., Kervyn, M., Canters, F., Bosshard-Stadlin, S.A., Songo, M.A.M., and Mattsson, H.B. (2015) Ash Fall Impact on Vegetation: A Remote Sensing Approach of the Oldoinyo Lengai 2007-08 Eruption. Journal of Applied Volcanology, 4, 15. https://doi.org/10.1186/s13617-015-0032-z

[36] Keller, J. and Zaitsev, A.N. (2006) Calciocarbonatite Dykes at Oldoinyo Lengai, Tanzania: The Fate of Natrocarbonatite. The Canadian Mineralogist, 44, 857-876. https://doi.org/10.2113/gscanmin.44.4.857

[37] Dawson, J.B. (1962) The Geology of Oldoinyo Lengai. Bulletin Volcanologique, 24, 349-387. https://doi.org/10.1007/BF02599356

[38] Carmody, L., Genge, M. and Jones, A.P. (2013) Carbonate Melts and Carbonatites. Reviews in Mineralogy \& Geochemistry, 75, 289-322.

[39] Zaitsev, A.N. and Keller, J. (2006) Mineralogical and Chemical Transformation of Oldoinyo Lengai Natrocarbonatites, Tanzania. Lithos, 91, 191-207. https://doi.org/10.1016/j.lithos.2006.03.018

[40] Saka, C. (2012) BET, TG-DTG, FT-IR, SEM, Iodine Number Analysis and Preparation of Activated Carbon from Acorn Shell by Chemical Activation with $\mathrm{ZnCl}_{2}$. Journal of Analytical and Applied Pyrolysis, 95, 21-24. https://doi.org/10.1016/j.jaap.2011.12.020

[41] Juárez, M.F.-D., Mostbauer, P., Knapp, A., Müller, W., Tertsch, S., Bockreis, A. and Insam, H. (2018) Biogas Purification with Biomass Ash. Waste Management, 71, 224-232. https://doi.org/10.1016/j.wasman.2017.09.043

[42] Makauki, E., King'ondu, C.K. and Kibona, T.E. (2017) Hydrogen Sulfide and Ammonia Removal from Biogas Using Water Hyacinth-Derived Carbon Nanomaterials. African Journal of Environmental Science and Technology, 11, 375-383. https://doi.org/10.5897/AJEST2016.2246

[43] Garces, H.F., Espinal, A.E. and Suib, S.L. (2012) Tunable Shape Microwave Synthesis of Zinc Oxide Nanospheres and Their Desulfurization Performance Compared with Nanorods and Platelet-Like Morphologies for the Removal of Hydrogen Sulfide. The Journal of Physical Chemistry C, 116, 8465-8474.

https://doi.org/10.1021/jp210755t

[44] Tseng, T.K., Chang, H.C., Chu, H. and Chen, H.T. (2008) Hydrogen Sulfide Removal from Coal Gas by the Metal-Ferrite Sorbents Made from the Heavy Metal Wastewater Sludge. Journal of Hazardous Materials, 160, 482-488. https://doi.org/10.1016/j.jhazmat.2008.03.058

[45] Seredych, M., Strydom, C. and Bandosz, T.J. (2008) Effect of Fly Ash Addition on the Removal of Hydrogen Sulfide from Biogas and Air on Sewage Sludge-Based Composite Adsorbents. Waste Management, 28, 1983-1992. https://doi.org/10.1016/j.wasman.2007.08.020

[46] Sitthikhankaew, R., Predapitakkun, S., Kiattikomol, R., Pumhiran, S., Assabumrungrat, S. and Laosiripojana, N. (2011) Comparative Study of Hydrogen Sulfide Adsorption by Using Alkaline Impregnated Activated Carbons for Hot Fuel Gas Puri- 
fication. Energy Procedia, 9, 15-24. https://doi.org/10.1016/j.egypro.2011.09.003

[47] Barnett, A., Pyle, L. and Subramanian, S.K. (1978) Biogas Technology in the Third World: A Multi-Disciplinary Review. International Development Research Centre, Ottawa.

[48] Li, K.-T., Yen, C.-S. and Shyu, N.-S. (1997) Mixed-Metal Oxide Catalysts Containing Iron for Selective Oxidation of Hydrogen Sulfide to Sulfur. Applied Catalysis A: General, 156, 117-130. https://doi.org/10.1016/S0926-860X(96)00417-6

[49] Kastner, J.R., Das, K., Buquoi, Q. and Melear, N.D. (2003) Low Temperature Catalytic Oxidation of Hydrogen Sulfide and Methanethiol Using Wood and Coal Fly Ash. Environmental Science \& Technology, 37, 2568-2574. https://doi.org/10.1021/es0259988

[50] Cheng, Z. and Liu, M. (2007) Characterization of Sulfur Poisoning of Ni-YSZ Anodes for Solid Oxide Fuel Cells Using in Situ Raman Microspectroscopy. Solid State Ionics, 178, 925-935. https://doi.org/10.1016/j.ssi.2007.04.004

[51] Ansari, A., Bagreev, A. and Bandosz, T.J. (2005) Effect of Adsorbent Composition on $\mathrm{H}_{2} \mathrm{~S}$ Removal on Sewage Sludge-Based Materials Enriched with Carbonaceous Phase. Carbon, 43, 1039-1048. https://doi.org/10.1016/j.carbon.2004.11.042

[52] Mathieu, Y., Tzanis, L., Soulard, M., Patarin, J., Vierling, M. and Molière, M. (2013) Adsorption of $\mathrm{SO}_{\mathrm{x}}$ by Oxide Materials: A Review. Fuel Processing Technology, 114, 81-100. https://doi.org/10.1016/j.fuproc.2013.03.019

[53] Itodo, A., Abdulrahman, F., Hassan, L., Maigandi, S. and Itodo, H. (2010) Application of Methylene Blue and Iodine Adsorption in the Measurement of Specific Surface Area by Four Acid and Salt Treated Activated Carbons. New York Science Journal, 3, 25-33.

[54] Bremner, J. and Banwart, W. (1976) Sorption of Sulfur Gases by Soils. Soil Biology and Biochemistry, 8, 79-83. https://doi.org/10.1016/0038-0717(76)90068-7

[55] Ducom, G., Radu-Tirnoveanu, D., Pascual, C., Benadda, B. and Germain, P. (2009) Biogas-Municipal Solid Waste Incinerator Bottom Ash Interactions: Sulphur Compounds Removal. Journal of Hazardous Materials, 166, 1102-1108. https://doi.org/10.1016/j.jhazmat.2008.12.024 